\title{
Effects of the Dow Jones Index and Rupiah Exchange Rate on the 2013-2017 Composite Stock Price Index
}

\author{
$\operatorname{Amanah}^{\bowtie}$ \\ Jurusan Ekonomi Pembangunan, Fakultas Ekonomi, Universitas Negeri Semarang \\ Permalink/DOI: https://doi.org/10.15294/efficient.v2i1.28794
}

Received: July 2018 ; Accepted: October 2018 ; Published: January 2019

\begin{abstract}
This study aims to examine the effect of the Dow Jones Index $\left(X_{1}\right)$ with the Composite Stock Price Index $(Y)$ in Indonesia and the influence between the rupiah exchange rate $\left(\mathrm{X}_{2}\right)$ on the Composite Stock Price Index $(Y)$ in Indonesia in the period 2013-2017. In statistical testing, the number o.2212 was obtained related to the influence of $X_{1}$ and $Y$, which means that every change in one unit of $X_{1}$ can lead to changes in $Y$ by $22 \%$, and means there is a weak influence between variables $X_{1}$ and $Y$ partially, while for the purpose of $X_{2}$ and $Y$ obtained the number 0.6531 , which means that every change in unit $X_{2}$ can result in a change in $Y$ by $65 \%$, which means there is a high influence between variables $X_{2}$ and $Y$ partially. In the $F$ test, $P$ Value is generated o.ooooo <0.05, which means there is a simultaneous influence between the two independent variables on the dependent variable, while the Determination Coefficient results in R-Squared value of 0.975966, which means a set of predictor variables in the model can explain the response variable $97 \%$, while the rest is explained by other variables outside the model under study.
\end{abstract}

Keywords: Dow Jones Index, Exchange Rate, Composite Stock Price Index

\begin{abstract}
Abstrak
Penelitian ini bertujuan untuk menguji pengaruh Indeks Dow Jones (Xı) dengan Indeks Harga Saham Gabungan (Y) di Indonesia dan pengaruh antara nilai tukar rupiah $\left(\mathrm{X}_{2}\right)$ terhadap Indeks Harga Saham Gabungan $(\mathrm{Y})$ di Indonesia pada periode 2013-2017. Dalam pengujian statistik, angka o,2212 diperoleh terkait dengan pengaruh $X_{1}$ dan Y, yang berarti bahwa setiap perubahan dalam satu unit Xı dapat menyebabkan perubahan Y sebesar $22 \%$, dan berarti ada pengaruh yang lemah antara variabel $X_{1}$ dan Y sebagian, sedangkan untuk keperluan $X_{2}$ dan Y diperoleh angka o,6531, yang berarti bahwa setiap perubahan dalam unit $\mathrm{X}_{2}$ dapat menghasilkan perubahan Y sebesar $65 \%$, yang berarti ada pengaruh yang tinggi antara variabel X2 dan Y secara parsial. Dalam uji $\mathrm{F}$, Nilai $\mathrm{P}$ dihasilkan o,ooooo <0,05, yang berarti ada pengaruh simultan antara dua variabel independen pada variabel dependen, sedangkan Koefisien Determinasi menghasilkan nilai R-Squared o,975966, yang berarti satu set variabel prediktor dalam model dapat menjelaskan variabel respon $97 \%$, sedangkan sisanya dijelaskan oleh variabel lain di luar model yang diteliti.
\end{abstract}

Kata Kunci: Indeks Dow Jones, Nilai Tukar, Indeks Harga Saham Gabungan

How to Cite: Amanah, A. (2019). Efek Indeks Dow Jones dan Nilai Tukar Rupiah terhadap Indeks Harga Saham Gabungan 2013-2017. EFFICIENT Indonesian Journal of Development Economics, 2(1), 362-369. https://doi.org/10.15294/efficient.v2i1.28794

(C) 2019 Semarang State University. All rights reserved

\footnotetext{
Alamat Korespondensi :

Alamat: Gedung L2 Lantai 2 FE Unnes

Kampus Sekaran, Gunungpati, Semarang, 50229

E-mail : amanahep@gmail.com
} ISSN 2655-6197 


\section{INTRODUCTION}

Capital markets hold an important role in the economic development of a country because it is a market aimed for various long-term financial instruments that can be traded both in form of debt and equity. The financial instruments traded on the capital market are such as stocks and bonds (Ernayani, 2015).

Capital markets run two functions, namely as a means for business funding and as a means for companies to get funds from investors. The funds obtained from capital markets can be used for the development of expansion efforts to increase working capital and others. Second, capital markets are means for people to invest financial instruments. In this way, public can place the risk of each financial instrument (Amin, 2012).

In Indonesia capital market trading is conducted on the Indonesia Stock Exchange. The Indonesia Stock Exchange drives economic growth because cheap funds can be obtained from capital markets although the performance is dynamic. The stock price on the stock exchange is not always stable, sometimes it can increases and can also decrease depending on the strength of demand and supply. In capital markets, fluctuations in stock prices result the stock exchange attractive to several investors. The flow of stock prices can be seen from the stock price index in the stock exchange as information needed by investors as a basis for their decisions in investment. One index in the exchange is the Composite Stock Price Index (CSPI).

Anoraga and Pakarti (2006) in Astuti et al. (2013), state that Composite Stock Price Index in an index showing the flow of stock prices which is generally recorded in the stock exchange and becomes a basis for the development of activities occurred in the capital market. Through this index, investors can examine the overall stocks available in the exchange. For more, for companies which actively carry out export and import activities, the stability of dollar exchange rate against rupiah is important. It is because when the rupiah value is depreciated by US dollar, the imported goods would be expensive. In relation to this, when the majority of the raw materials used by a company is obtained through import, automatically the depreciation would increase the production cost. This increase would certainly reduce the level of company profit. This reduction would surely influence investors' buying interest in the company stocks.

Commonly, this phenomenon will drive the weakening of stock price index in the country. Another economic variable available to use for examining the economic performance of a country is the country's stocks index itself. It is possible because when the country has a bright economic outlook, automatically investors will be attracted to invest their funds in the capital market of the country concerned. This will encourage bullish periods that will drive the flow of the stock index. Conversely, when the country's economic atmosphere looks dull, it will be known by the decrease in the stocks index. Other than that, in United States of America, the index that can be used as a proxy is the Dow Jones Index. The Dow Jones Index is the oldest stock market index in the United States and is a representation of the most important industrial performance in the United States.

Companies listed on the Dow Jones Index are generally multinational companies. Their operations are spread throughout the world. Companies like Coca-Cola, ExxonMobil, 
Citigroup, Procter \& Gamble are some example of companies listed in Dow Jones and operating in Indonesia. These companies generally operate directly in Indonesia. When the Dow Jones index goes up, it means that the economic performance of the United States in general is in a good position. With good economic conditions, the Indonesian economy realized through export activities and the capital market will be driven (Sunariyah, 2006).

Based on the description above, a research question for this study was "Do Dow Jones Index and Rupiah Exchange Rate affect the Composite Stock Price Index (CSPI)?" Meanwhile, the aim of this study was to obtain empirical evidence whether the variables of Dow Jones Index and the Value of Rupiah Exchange of influence the Composite Stock Price Index.

\section{RESEARCH METHODOLOGY}

This study used correlational study, namely a study carried out to find the existence of relationship and how significant the relationship is as well as whether the relationship is significant or not (Arikunto, 2002: 239). In this case, the correlational study was aimed at investigating either partial or simultaneous influence of inflation, exchange rate, and Dow Jones, and net exports to the Composite Stock Price Index (CSPI).

Suharyadi and S.K., (2009: 7) argue that population is a collection of all possible people, objects, and other sizes involved as an object of concern or all objects of concern. The population in this study were all companies listed on the Indonesia Stock Exchange from January 2013 - December 2015.

According to Sugiyono (2011: 62), sample is a part of number and characteristics owned by population. The sampling technique used in this study was by using saturated sampling technique. This is a technique used when all population members are involved as samples (sugiyono, 2011: 68). The sample in this study were all companies registered in Indonesia Stock Exchange from January 2013-December 2015.

This study used ne dependent variable, and three independent variables. Dependent variable is a variable influenced or act as a cause of the existence of independent variable (Sugiyono, 2011:4). Meanwhile, independent variable in this study was Composite Stock Price Index (CSPI), which was the closing price of the monthly CSPI stocks in Indonesia Exchange Stock occurred between 2013 and 2015 (in rupiah).

Independent variable (X), According to Sugiyono (2011: 4), is a variable that influences or is the cause of the change or the emergence of the dependent variable. The independent variable in this study was the level of Indonesia year-end inflation determined by Bank Indonesia ranging from 2013 until 2017 (in percentage).

Classical Assumption Test is used to find out whether the results of the model analysis in the study are free from classical assumptions deviations. In this study, the classical assumption test used covered multicollinearity test, heteroscedasticity test, autocorrelation test, and normality test.

In a good regression model, there should be no correlation between independent variables. To detect the presence or absence of multicollinearity in the regression model, several ways can be used such as (1) tolerance value and the opposite (2) variance inflation factor (VIF). Both of these measures indicate which 
independent variables explained by other independent variables.

Further, heteroscedasticity test is a test used to assess whether there is an inequality of variants from residuals for all observations in the linear regression model.

Auto Correlation test is carried out to determine whether or not there is a classical deviation of autocorrelation, namely the correlation between the residuals at the time of observation and other observations in the regression model. In this study, auto correlation test was done by using the Durbin-watson test (DW Test).

According to Ghozali (2013: 160) normality test has a purpose to test whether in the regression model, the residual confounding variable has a normal distribution. There are two ways to detect whether the residual is normally or not normally distributed.

The basis for decision making to accept or reject $\mathrm{Ho}$ and $\mathrm{Ha}$ was by using the value of significance probability by considering if $t$ test is negative, the hypothesis is rejected (the regression coefficient is not significant). It means that partially, the independent variables do not have significant influence on the dependent variable. For more, when the $\mathrm{f}$ test results positive value, the hypothesis is accepted (the regression coefficient is significant). It means that partially the independent variables have significant influence on dependent variables.

The $\mathrm{F}$ test aims to determine whether or not there is a simultaneous effect (together) given by independent variables (X) on dependent variables (Y). Alternatively, determination coefficient serves to find out the number of percentage of influence given by variable $\mathrm{X}$ simultaneously to variable $\mathrm{Y}$. The data source used in this study were secondary data. Secondary data is data in the form of documentation or report (Azwar, 2015: 91).

In this study the researchers used data from the publication of the Central Bureau of Statistics (www.bps.go.id), Bank Indonesia (www.bi.go.id), the Indonesia Stock Exchange published by yahoo finance website (finance.yahoo.com), Bank Indonesia published by kontan website (sentraldata.kontan.co.id).

\section{RESULTS AND DISCUSSION}

The model in this study was tested by covering classic assumption tests and statistical tests. The followings were the results:

Table 1. Multicollinearity Test Results Variance Inflation Factors

Date: 08/27/18 Time: 03:18

Sample: 2013-2017

Included observations: 5

\begin{tabular}{lll}
\hline & $\begin{array}{l}\text { Uncentered } \\
\text { Variables }\end{array}$ & $\begin{array}{l}\text { Centered } \\
\text { VIF }\end{array}$ \\
C & 423.5439 & NA \\
EXCHANGE_RATE & 533.4169 & 1.281425 \\
INDEKS_DJ & 67.10553 & 1.281425
\end{tabular}

Source: Research Data (E-Views 9.0)

The table above shows that the Centered VIP values for Dow Jones Index and the Exchange Rate was 1. 281425 where the value was less than 10. Therefore, it can be said that there was no multicollinearity problem in the prediction model. The heteroscedasticity test was a test used to assess the presence of an inequality of variance from the residual for all observations in the linier regression model. The result of this test can be seen in table 3. Table 3 
shows that the value of $\mathrm{P}$ was showed by the accepted or the regression model was Chi-square probability value of 0.1402 . homoscedastic or there was no problem on the Therefore, $\mathrm{p}$ value $0.1402>0.05$, then Ho was assumption of non-heteroscedasticity.

Table 2. Heteroscedasticity Test Results

Heteroscedasticity Test: Breusch-Pagan-Godfrey

\begin{tabular}{llll}
\hline F-statistic & 3.668238 & Prob. F(2,2) & 0.2142 \\
Obs*R-squared & 3.928932 & Prob. Chi-Square(2) & 0.1402 \\
Scaled explained SS & 0.413434 & Prob. Chi-Square(2) & 0.8132
\end{tabular}

Source: Research Data (E-Views 9.0)

Auto correlation test was done to know whether there is a deviation of autocorrelation classical assumption, namely a correlation happens between residual in an observation and in other observations in regression model. In this study, this test was conducted by the use of Durbinwatson test (DW test), and the results are in the table 3 in the appendix.

Normality test is done with the aim of examining data distribution in a group of data or variable. It is whether the data are normally distributed or not. Based on figure 1, the value of jarque bera was 0.306681 with $\mathrm{p}$ value of $0.857838>0.05$. Therefore, it can be said that the residual was normally distributed.

$\mathrm{T}$ test was conducted with the aim of knowing whether the independent variable $(\mathrm{X})$ partially has a significant influence on the dependent variable $(\mathrm{Y})$. Whereas, $\mathrm{F}$ test or known as the simultaneous test / ANOVA test is a test to see how the all variables are jointly influenced on the dependent variable.

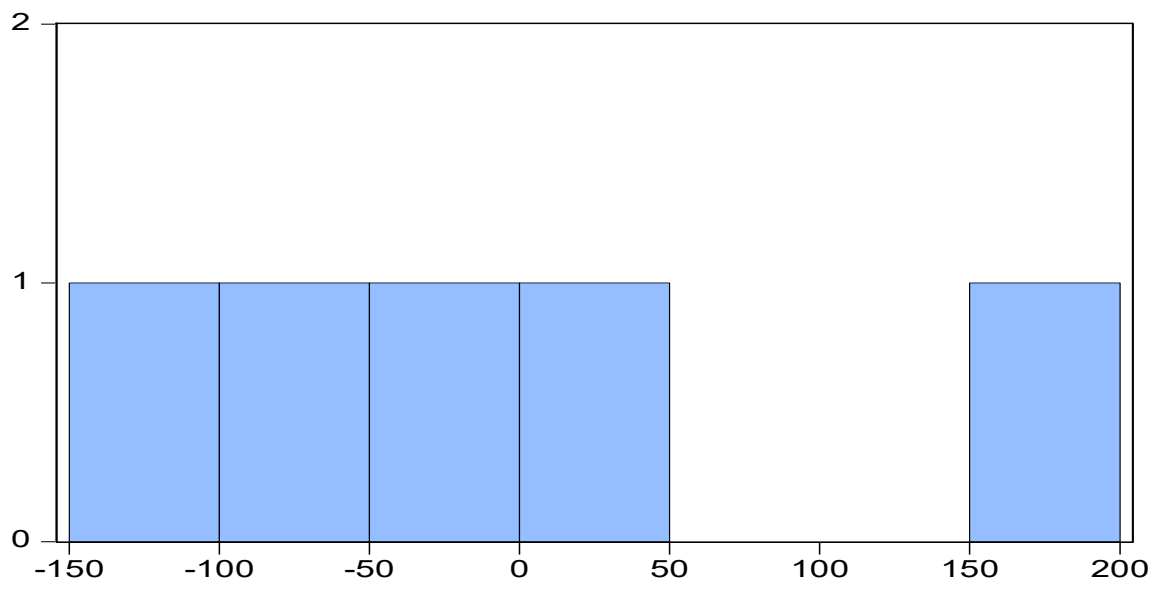

\begin{tabular}{lr} 
Series: Residuals \\
Sample 2013 2017 \\
Observations & \multicolumn{2}{|l}{} \\
Mean & $1.85 e-13$ \\
Median & -16.45032 \\
Maximum & 179.3846 \\
Minimum & -139.7117 \\
Std. Dev. & 117.7513 \\
Skewness & 0.500830 \\
Kurtosis & 2.315350 \\
& \\
Jarque-Bera & 0.306681 \\
Probability & 0.857838
\end{tabular}

Figure 1. The results of the normality test.

Source: Research Data (E-Views 9.0) 
The following table 4 shows that the $\mathrm{P}$ value was 0.021679 where $<0.05$. It can be concluded that $\mathrm{H}_{1}$ was accepted. The acceptance of $\mathrm{H}_{1}$ means that the independent variable simultaneously influenced the dependent variable. Further, determination coefficient functions to find out the percentage of influence given by variable $\mathrm{X}$ simultaneously to variable $\mathrm{Y}$.
Based on table 4, it can be seen that the determination coefficient value or R-Squared was 0.978321 , meaning that a set of predictor variables in the model could explain the response variable by $97 \%$, while the rest was explained by other variables outside the investigated model.

Table 4. Test Statistics

\begin{tabular}{|c|c|c|c|c|}
\hline Variables & Coefficients & Std. Error & t-Statistic & Prob. \\
\hline $\bar{C}$ & 855.6683 & 1532.657 & 0.558291 & 0.6328 \\
\hline EXCHANGE_RATE & -0.070398 & 0.131325 & -0.536063 & 0.0000 \\
\hline INDEKS_DJ & 0.782818 & 0.090705 & 8.630358 & 0.0000 \\
\hline R-squared & 0.978321 & \multicolumn{2}{|c|}{ Mean dependent var } & $5149 \cdot 300$ \\
\hline Adjusted R-squared & 0.956642 & \multicolumn{2}{|c|}{ S.D. dependent var } & 799.7395 \\
\hline S.E. of regression & 166.5255 & \multicolumn{2}{|c|}{ Akaike info criterion } & 13.35188 \\
\hline Sum squared resid & 55461.49 & \multicolumn{2}{|c|}{ Schwarz criterion } & 13.11755 \\
\hline Log likelihood & -30.37971 & \multicolumn{2}{|c|}{ Hannan-Quinn criter. } & 12.72295 \\
\hline F-statistic & 45.12810 & \multicolumn{2}{|c|}{ Durbin-Watson stat } & 2.305178 \\
\hline Prob(F-statistic) & 0.021679 & & & \\
\hline
\end{tabular}

Source: Research Data (E-Views 9.0)

\section{CONCLUSION}

Based on the findings and discussion on the influence of the Dow Jones index and the rupiah exchange rate on the Composite Stock Price Index, the researchers draw several conclusions, namely first, the Dow Jones Index has a positive influence of $22 \%$, meaning that there is a weak correlation with the Composite Stock Price Index. Second, the rupiah exchange rate has a positive effect of $65 \%$ on the Composite Stock Price Index, meaning that there is a strong influence between the exchange rate and the Composite Stock Price Index, and based on the F Test, there is no simultaneous effect between the two independent variables on the dependent variable.

\section{REFERENCES}

Tunggal, Wijaya Amin. 2012. Internal Auditing, Edisi Lima. Yogyakarta : BPFE

Anoraga \& Pakarti. 2006. Pengantar Pasar Modal. Jakarta : PT Rineka Cipta

Arikunto, S. 2006. Prosedur Penelitian Suatu Pendekatan Praktik Edisi Revisi. Jakarta : PT Rineka Pustaka

Astuti, R., E.P., Apriatni, dan Susantra, H. 2013. Analisis Pengaruh Tingkat Suku Bunga (SBI), Nilai Tukar (KURS) Rupiah , Inflasi, dan Indeks Bursa Internasional terhadap IHSG (Studi pada IHSG di BEI Periode 2008-2012). Diponegoro Journal of Social and Politic of Science. 
Azwar, Saifuddin. 2015. Metode Penelitian. Yogyakarta: Pustaka Pelajar.

Ernayani, Rihfenti. 2015. Pengaruh Kurs Dollar, Indeks Dow Jones dan Tingkat Suku Bunga SBI Terhadap IHSG. Jurnal Sains Terapan Vol 10 Number (1)

Ghozali, Imam. 2011. Aplikasi Analisis Multivariate dengan Program IBM SPSS 19. Semarang: Badan Penerbit Universitas Diponegoro.

Jose, Rizal Joesoef, 2007. Pasar Uang dan Pasar Valuta Asing, Salemba Empat, Jakarta.

Mishkin, Frederic S. 2008. Ekonomi Uang, Perbankan dan Pasar Keuangan. Jakarta: Salemba Empat

Samsul, Mohamad. 20o6. Pasar Modal dan Manajemen Portofolio. Jakarta: Erlangga.
Siamat, Dahlan. 2004. Manajemen Lembaga Keuangan Edisi Keempat. Jakarta : Lembaga Penerbit Fakultas Universitas Indonesia

Sugiyono. 2011. Statistika untuk Penelitian. Bandung: Alfabeta.

Suharyadi, dan S.K., Purwanto. 2009. Statistika untuk Ekonomi dan Keuangan Modern. Jakarta: Salemba Empat.

Sunariyah. 2006. Pengantar Pengetahuan Pasar Modal. Yogyakarta: Unit Penerbit dan Percetakan Sekolah Tinggi Ilmu Manajemen YKPN.

Widiatmodjo, Sawiji. 20o8. Cara Sehat Investasi di Pasar Modal. Edisi Revisi. Jakarta : PT Elex Media Computindo.

\section{APPENDIX}

Table 3. The Results of Autocorrelation Test

Dependent Variable: IHSG

Method: Least Squares

Date: 08/27/18 Time: 03:29

Sample: 20132017

Included observations: 5

\begin{tabular}{llll}
\hline R-squared & 0.978321 & Mean dependent var & 5149.300 \\
Adjusted R-squared & 0.956642 & S.D. dependent var & 799.7395 \\
S.E. of regression & 166.5255 & Akaike info criterion & $\mathbf{1 3 . 3 5 1 8 8}$ \\
Sum squared resid & 55461.49 & Schwarz criterion & $\mathbf{1 3 . 1 1 7 5 5}$ \\
Log likelihood & -30.37971 & Hannan-Quinn criter. & $\mathbf{1 2 . 7 2 2 9 5}$ \\
F-statistic & 45.12810 & Durbin-Watson stat & $\mathbf{2 . 3 0 5 1 7 8}$ \\
Prob(F-statistic) & 0.021679 & &
\end{tabular}

